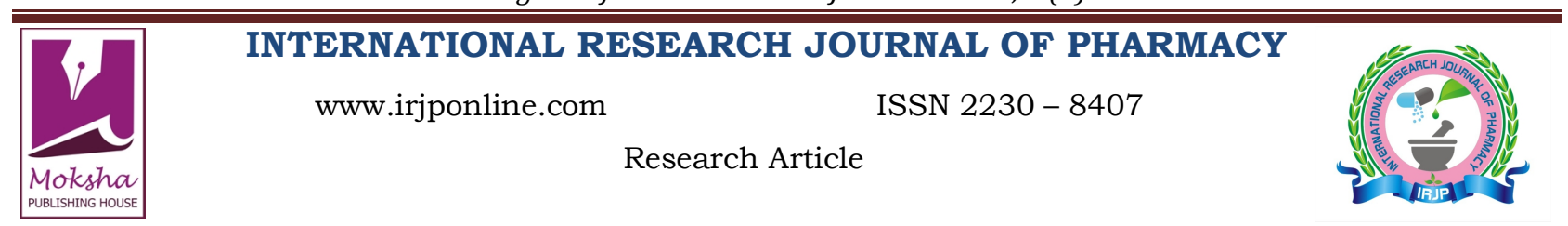

\title{
A STUDY ON ETHNOMEDICINAL USES OF PLANTS IN DHEMAJI DISTRICT OF ASSAM WITH SPECIAL REFERENCE TO REPRODUCTIVE HEALTH
}

\author{
Lagachu Jinu* and Kalita Jogen Chandra \\ ${ }^{1}$ Animal Physiology and Biochemistry Laboratory, Department of Zoology, Gauhati University, Assam, India \\ Email: aarhi0004@gmail.com
}

Article Received on: 10/01/13 Revised on: 01/02/13 Approved for publication: 11/03/13

DOI: $10.7897 / 2230-8407.04356$

IRJP is an official publication of Moksha Publishing House. Website: www.mokshaph.com

(C) All rights reserved.

\begin{abstract}
The present paper deals with the documentation of ethnomedicinal uses of plants and parts, particularly the fertility and anti-fertility plants used by the Misings, Kacharis \& Chutias of Dhemaji district of Assam, India. Dhemaji is situated between the $94^{\circ} 12^{\prime} 18^{\prime \prime}$ E \& $95^{\circ} 41^{\prime} 32^{\prime}$ ' E longitudes \& $27^{\circ} 05^{\prime} 27^{\prime}$ ' N \& $27^{\circ} 57^{\prime} 16^{\prime \prime} \mathrm{N}$ latitudes, the district covers an area of $3237 \mathrm{sq} . \mathrm{km} \&$ is a basically plain area lying at an altitude of $104 \mathrm{~m}$ above the mean sea level. It is inhabited by large number of indigenous tribes, namely, Mishings, Kacharis, Bodos, Deoris....etc. Survey was carried out during the period January 2011 to July 2012, in 12 villages to investigate about the above mentioned indigenous medicinal plants used for the management and cure of female reproductive health problems. Total 11 species of plants were reported. It is observed that in majority of cases, plants are mixed together and consumed.
\end{abstract}

Keywords: Ethnomedicinal, Fertility, Anti-fertility

\section{INTRODUCTION}

The World Health Organization in 2001 estimated that eighty percent of the world population use medicinal plants in the treatment of diseases. ${ }^{7}$....It was also estimated that upto $90 \%$ of the population in developing countries rely on the use of medicinal plants to help meet their primary health care needs. ${ }^{2}$

Infertility is a worldwide medical and social problem. Infertility in itself may not threaten physical health but can have serious impact on the mental and social well being of infertile couple. It is estimated that there are 60-80 million infertile couples worldwide and above $10-15 \%$ of married couples are affected. ${ }^{1}$ Similarly, rising human population throughout India more particularly in developing and underdeveloped parts has detrimental effect on the life supporting system. Fertility regulation, comprising contraception and management of infertility forms an important component of reproductive health. Though considerable progress has been made in the development of highly effective, acceptable and reversible methods of contraception among females, the development of new fertility drugs from medicinal plants is an attractive preposition. A wide variety of synthetic fertility enhancing and contraceptive treatments are available but most of them are associated with some health problems. In such circumstances ayurvedic or ethnological drugs can be found useful. The folklore information and the ancient literature about the plants and herbs can help.

Ethnobotany is a multidisciplinary study involving the relationship between plants and the aboriginal people $\&$ a fair familiarity with the flora and the vegetation of the region. North Eastern India offers an immense scope for such ethnobotanical studies since it is mostly inhabited by numerous aboriginal tribes having rich folklore. Assam, situated in the North Eastern region of India is inhabited by the largest number of tribes, namely, Mishings, Deoris, Rabhas, Boro, Kacharis,....etc.

This study was carried out to search for information from traditional medical practitioners on plant remedies used for the management and cure of female fertility and conctraceptive problem.

\section{Survey area}

Dhemaji is situated in the remote corner of Assam. Geographically, it is situated between the 94 $12^{\prime} 18^{\prime}$ ' E \& $95^{\circ}$ E Longitudes \& $27^{\circ} 05^{\prime} 27^{\prime}$ ' N 27 $57^{\prime} 16^{\prime}$ ' N Latitudes. The district covers an area of 3237 sq. km. \& is a basically plain area lying at an altitude of $104 \mathrm{~m}$ above the mean sea level. It is inhabited by large number of tribes, namely, Mishings, Deoris, Kacharis, Bodos...etc

\section{METHODOLOGY}

A survey was carried out during the period 2011-12 to collect information on fertility and ant-fertility medicinal plants used by the local inhabitants of Dhemaji district of Assam. The study was done in 12 villages selected randomly. The methodology followed includes different parameters. The most important among them was the people participatory. The basic information for this investigation has been collected through the methods such as, direct personal investigation, indirect oral investigation and questionnaires \& schedules. The formal discussion consisted of the headman, healers, both men \& women and common cultivators. Information about the plants were recorded with regard to their vernacular names, plant part used, process of preparation of medicine...etc. Plants were collected \& identified using relevant floras \& standard literature

\section{RESULTS}

The fertility enhancing \& anti-fertility plants were recorded and the information is presented in tabular form (table1). The abbreviation " $A$ " stands for Assamese and " $M$ " for Mishing. The present study reported 11 species of plants belonging to different families. It is found that maximum of the plant species are given in conjunction with one another as compound drugs. 


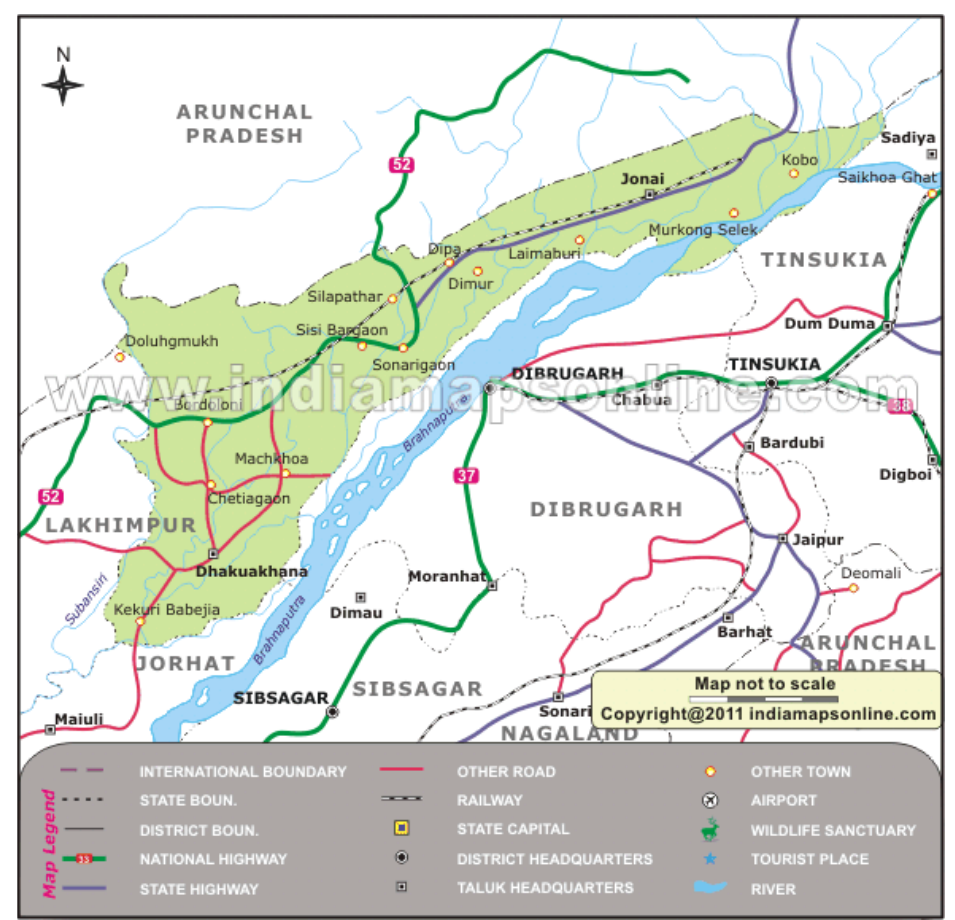

Table 1: List of fertility enhancing plants used by the local inhabitants of Dhemaji district

\begin{tabular}{|c|c|c|c|c|c|c|}
\hline SI. & $\begin{array}{c}\text { Plant name } \\
\text { (Family) }\end{array}$ & English name & Local names & Treatment & $\begin{array}{l}\text { Parts } \\
\text { used }\end{array}$ & Folk use \\
\hline 1. & $\begin{array}{l}\text { Paedaria scandens } \\
\quad \text { (Rubiaceae) }\end{array}$ & $\begin{array}{c}\text { Stink-vine, } \\
\text { Chinese-fever } \\
\text { vine } \\
\end{array}$ & $\begin{array}{c}\text { Bedailata (A), } \\
\text { Bungkeripuk (M) }\end{array}$ & Fertility & Leaves & $\begin{array}{l}\text { It is boiled with Drymaria cordata in ratio } \\
\text { (1:1) and filtered. The filtrate is taken twice } \\
\text { per day during Mensuration }\end{array}$ \\
\hline 2. & $\begin{array}{l}\text { Scoparia dulcis Linn. } \\
\text { (Scrophulariaceae) }\end{array}$ & $\begin{array}{c}\text { Goatweed, } \\
\text { Scoparia-weed }\end{array}$ & Mitha-paat (A) & -do- & $\begin{array}{c}\text { Tender } \\
\text { shoot }\end{array}$ & $\begin{array}{l}\text { Paste is made along with Paedaria scandens } \\
\text { in the ratio }(2: 1) \text {. Taken } 3 \text { times per day for } \\
2 \text { days during mens. }\end{array}$ \\
\hline 3. & $\begin{array}{l}\text { Hibiscus rosa sinensis } \\
\text { (Malvaceae) }\end{array}$ & China-rose & $\begin{array}{c}\text { Jova-phul } \\
(\mathrm{A}, \mathrm{M})\end{array}$ & -do- & Flower & $\begin{array}{l}\text { Paste is made along with Cynodon dactylon } \\
\text { Linn. Taken for } 3 \text { days during mens. }\end{array}$ \\
\hline 4. & $\begin{array}{l}\text { Drymaria cordata A. } \\
\text { Gray. } \\
\text { (Caryophyllaceae) }\end{array}$ & $\begin{array}{c}\text { Tropical } \\
\text { Chickweed }\end{array}$ & Laijabori (M) & -do- & $\begin{array}{c}\text { Whole } \\
\text { plant }\end{array}$ & Same as Paedaria scandens \\
\hline 5. & $\begin{array}{l}\text { Musa paradisiaca } \\
\text { (Musaceae) }\end{array}$ & Banana & Malbhug kol (A) & - do- & Fruit & $\begin{array}{l}\text { Ripe banana part is mixed with "lightning } \\
\text { bugs" and taken orally at } 7^{\text {th }} \text { day of mens. }\end{array}$ \\
\hline 6. & $\begin{array}{c}\text { Ferula asafetida } \\
\text { (Apiaceae) }\end{array}$ & Devil's dung & Hing $(\mathrm{H}, \mathrm{A})$ & -do- & $\begin{array}{l}\text { Latex, } \\
\text { Resin }\end{array}$ & Once per day before 2 days of mens. \\
\hline 7. & $\begin{array}{l}\text { Mimosa pudica } \\
\text { (Fabaceae) }\end{array}$ & Touch-me-not & Lajukia bon $(A)$ & Anti-fertility & $\begin{array}{c}\text { Tender } \\
\text { shoot }\end{array}$ & $\begin{array}{c}\text { Paste is made with roots of Terminalia } \\
\text { chebula in ratio( } 1: 1) \text { and taken at the third } \\
\text { day of mens., thrice/day }\end{array}$ \\
\hline 8. & $\begin{array}{l}\text { Terminalia chebula } \\
\text { (Combretaceae) }\end{array}$ & $\begin{array}{l}\text { Chebulic } \\
\text { myrobal-an }\end{array}$ & Hilika (A, M) & -do- & Root & Same as above \\
\hline 9. & $\begin{array}{c}\text { Plumbago rosea } \mathrm{L} \text {. } \\
\text { (Plumbaginaceae) }\end{array}$ & Indian leadwort & Agechita(A) & $\begin{array}{c}\text { Anti- } \\
\text { implantation }\end{array}$ & Root & Root is worn as garland to expel embryo \\
\hline 10 & $\begin{array}{l}\text { Musa acuminate } \\
\text { (Musaceae) }\end{array}$ & Banana & $\begin{array}{c}\text { Kol (A) } \\
\text { Kopak (M) }\end{array}$ & -do- & $\begin{array}{l}\text { Inflo- } \\
\text { rescenc } \\
\mathrm{e}\end{array}$ & $\begin{array}{l}\text { It is burnt and eaten for 3-4 days during } \\
\text { mens. }\end{array}$ \\
\hline 11 & $\begin{array}{c}\text { Carrica papaya } \\
\text { (Caricaceae) }\end{array}$ & Papaya & Omita (A) & -do- & Fruit & Taken during gestation period \\
\hline
\end{tabular}

\section{DISCUSSION}

The traditional plants used by the local people in their day-today life have got various ethnomedicinal properties. The indigenous medicinal plants prescribed by the local healers for treating various diseases are normally used as food by the tribes of this region. It is seen that the various plants used by the tribes are found nearby their settlement. Though the traditional plants used by them are wild, they domesticated and conserved them nearby their house. Thus, utilization \& conservation practices of the native tribes are interwined. Unfortunately, the availability of all types of modern facilities \& degradation of resources have made its younger generation to abandon their traditional practices \& discard their rich indigenous knowledge. Hence, we suggest research work \& phytochemical investigation of the indigenous plants of this region are to be given priority, as otherwise this indigenous knowledge would get extinct forever \& would be a great threat to the welfare of human mankind

\section{ACKNOWLEDGEMENT}

The authors are thankful to the Department of Zoology \& Department of Botany, Gauhati University (Assam) for providing the necessary facilities. They are also grateful to the villagers \& people of the studied areas for their immense help \& co-operation. 


\section{REFERENCES}

1. Erhabor J. O., Idu M. \& Udo F. O. Ethnomedicinal survey of medicinal plants used in the treatment of male infertility among the IFA Nkari people of Ini local government area of Akwa Ibom state, Nigeria. Research Journal of Recent Sciences. 2013; 2:5-11.

2. WHO. Traditional medicine-growing needs \& potentials. WHO Pol. Persp. On Med. 2002; 2: 1-6.

3. Jain S. K. \& Rao R. R., "Handbook of field \& Herbarium method, New Delhi, 1977.

4. Jain SK \& Goel AK: Workshop Exercise 1. Proforma for Field Work. A manual of Ethnobotany. Scientific Publisher, Jodhpur, 1995.

5. Kanjilal U. N., Kanjilal P. C. \& Das A., "Flora of Assam", Shillong, Omsons Publications, New Delhi1934-1940; 5 vols.

6. Sharma U. K \& Pegu S., "Ethnobotany of religious \& supernatural beliefs of the Mishing tribes of Assam with special reference to the 'Dobur Uie',". 2011. J. Ethnobiol. Ethnomed;7:6. http://dx.doi.org/

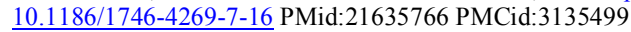

7. Upadhyay K. A., Kumar K., Kumar A. \& Mishra A. K. "Tinospora cordifolia (Willd.) Hook. F. \& Thomas. (Guduchi)-validation of the Ayurvedic pharmacology through experimental \& clinical studies,". 2010. Int. J. Ayurveda Res.; 1(2): 112-121. http://dx.doi.org/10.4103/ 0974-7788.64405 PMid:20814526 PMCid:2924974

8. WHO. Legal Status of Traditional Medicine \& Complementary \& Alternative medicine: A worldwide Review, 200(2001)

9. Chatterjee S, Saikia A, Dutta P, Pangging G and Goswami AK; Biodiversity significance of North East India. Forest Conservation Programme WWF India.

10. Dutta BK and Dutta PK: Potential of ethnobotanical studies in North Eastern India: An overview. Indian Journal of Traditional Knowledge. 2005;4(1):7-14

Cite this article as:

Lagachu Jinu and Kalita Jogen Chandra. A study on ethnomedicinal uses of plants in Dhemaji district of Assam with special reference to reproductive health. Int. Res. J. Pharm. 2013; 4(3):261-263 